\title{
Realizácia outdoorovej edukácie vo vybraných krajinách zapojených do Outward Bound International
}

\author{
Ján Kancír, Sofia Šolcová \\ Katedra prírodovedných a technických disciplín, Pedagogická fakulta, \\ Prešovská univerzita v Prešove
}

Redakci zasláno 14. 12. 2020 / upravená verze obdržena 16. 2. 2021 / / k uveřejnění přijato 17. 2. 2021

\begin{abstract}
Abstrakt: V edukačnom prostredí väčšiny vyspelých krajín sa v ostatných dekádach čoraz intenzívnejšie uplatňuje koncepcia outdoorovej edukácie. Pobyt vo vonkajšom prostredí je jednou z dôležitých podmienok zdravého rozvoja dietatáa. Má vel'ký význam pre jeho telesný, kognitívny, sociálny, emocionálny vývin a taktiež prispieva k rozvoju jeho klúčových kompetencií. Outdoorové aktivity majú nezastupitel'nú úlohu vo výchove a vzdelávaní diet’ata. Pomáhajú mu porozumiet' okolitému svetu, ktorý je reálnym priestorom jeho súčasnej i budúcej existencie. Z tohto hladiska outdoorové vzdelávanie disponuje edukačným potenciálom, ktorý je nenahraditel'ný pri optimalizácii komplexného rozvoja osobnosti žiaka. Cielom predkladanej štúdie je poukázat' na osobitosti outdoorovej edukácie, historický kontext, súčasnost' a budúcnost' jej uplatnenia v edukačnej praxi u nás i v zahraničí. V prvej časti sa venujeme filozofickým východiskám, teórii a praxi experienciálneho učenia. Nasleduje analytická komparácia realizácie outdoorovej edukácie vo vybraných krajinách. Tieto krajiny sú súčastou svetovo etablovanej organizácie Outward Bound International zameranej (práve?) na outdoorovú edukáciu. Komparácia je spracovaná na báze analýzy informačných zdrojov z plno-textových databáz Proquest, Scopus, Web of science a d’alších. Boli využité literárne metódy, analýza pedagogických dokumentov a literárnych zdrojov našej i zahraničnej proveniencie. $V$ závere ponúkame stručné zhrnutie predmetnej problematiky v podobe prehl'adnej tabul'ky. Súčastou štúdie sú aj návrhy na uplatnenie pozitívnych zmien v edukačnej praxi na Slovensku.
\end{abstract}

Kl'účové slová: outdoorová edukácia, Outward Bound International, formálne a neformálne vzdelávanie, komparatívna analýza

V našej literatúre sa $\mathrm{s}$ pojmom výchova $v$ prírode najčastejšie stretávame v knihách od E. T. Setona a A. B. Svojsíka, ktorí sú zakladatel'mi skautských organizácií na našom území. Najviac sa však pojem výchova v prírode alebo outdoor education používa v odbornej literatúre v zahraničí. Tento pojem sa v posledných rokoch vyvíja a zmeny $\mathrm{v}$ jeho obsahu ovplyvňujú aj samotnú 
prax (Neuman et al., 2000). V našom článku budeme využívat' pojem outdoorová edukácia, ktorý sa na Slovensku etabloval a je pre naše výskumné zameranie vhodnejší, ked'že tento pojem širšie poníma nielen výchovu v prírode, ale aj výchovu vo vonkajšom prostredí. Cielom predkladanej štúdie je poukázat' na význam a edukačný potenciál outdoorovej edukácie v procese komplexného rozvoja osobnosti žiaka. Súčastou príspevku je aj komparácia realizácie outdoorovej edukácie vo vybraných štátoch, ktoré sú súčastou svetovej organizácie, Outward Bound International. Do tejto organizácie patrí viac ako 30 krajín sveta. Výber jednotlivých štátov bol realizovaný na základe toho, aké bohaté majú dané štáty historické skúsenosti s realizáciou outdoorovej edukácie a ako majú rozpracovaný jej obsah v rámci formálneho i neformálneho vzdelávania. V rámci komparácie sme sa samozrejme zamerali aj na Slovensko a Českú republiku.

\section{Historický prierez outdoorovej edukácie}

Pohybové aktivity v prírode siahajú až do obdobia starovekého Grécka. Neskôr, v období renesancie a osvietenstva, sa už vyskytujú aj rôzne turistické aktivity v prírode. Podstatný rozmach však zaznamenávame až v osemnástom storočí (Kompán \& Görner, 2007). 0 výchovu v súlade s prírodou sa snažili už J. A. Komenský, J. Lock či J. J. Rousseau. Rousseau vo svojom diele Emil alebo o výchove predstavuje výchovu, ktorá je spätá s prírodou a prirodzenými dôsledkami. Moderné outdoorové vzdelávanie nemá jedného konkrétneho zakladatel'a, ale za svoj vznik vd’ačí mnohým iniciatívam. Už na prelome 19. a 20. storočia sa v Európe, USA, Austrálii a na Novom Zélande objavilo prvé organizované kempovanie (Kancír et al., 2020). Prvé skautské hnutie bolo založené 1907 Robertom Baden-Powellom a podporovalo neformálne vzdelávanie a aktivity praktizované $\mathrm{v}$ prírode. Prvé outdoorové centrum bolo založené vo Walse po skončení druhej svetovej vojny. V polovici 20. storočia nastáva rozmach outdoorového vzdelávania v edukačných systémoch mnohých krajín. Prvé začiatky skautingu v rámci východnej Európy zaznamenávame v Nemecku, kde už v roku 1809 bola vytvorená prvá gymnastická skupina, ktorá sa následne angažovala v skautingu. Analogické situácie priekopníkov v športoch sa odohrávali aj v iných štátoch, ako napríklad Pol'sko, Grécko, Chorvátsko, Turecko. Práve v Chorvátsku sa stali zakladatel'mi Vinkovci. V Grécku vedúci skautov vyšli z atletickej asociácie. V Pol'sku bola prvá inštitúcia zaujímajúca sa o skauting Sokol. V Rusku založil v roku 1920 prvú skautskú skupinu Oleg Pantuchov (Ford, 1986). Skauting na Ukrajine 
bol založený viacerými zakladatel'mi a to Alexandrom Tiskovským, Petrom Frankom a Ivanom Chmolom v meste L'vov, kde fungovali na dvoch vetvách ako dievčenský a chlapčenský skauting (Kozik, 2017). Dovolíme si spomenút' niektoré významné roky, ktoré podmienili vznik outdoorovej edukácie vo svete. V roku 1886 sa narodil Kurt Hahn, ktorý je považovaný spolu s L. Holtem, za zakladatelov outdoorového vzdelávania a rôznych d’alších hnutí zaoberajúcich sa zážitkovým učením. V roku 1920 pod vedením pedagóga Kurta Hahna vznikla Salemská škola, ktorá sa zameriavala na osobnostný rozvoj, rovnost', úctu, sociálnu spravodlivost’ a komunitnú službu v Nemecku. Rok 1940 je datovaný ako vznik hnutia Outward Bound, ktoré je zamerané na zážitkové vzdelávanie v outdoorovom prostredí. Okrem toho sa zameriava aj na rozvíjanie afektívnej stránky osobnosti, ako sú sociálne zručnosti tolerancia, zodpovednost', empatia, komunikácia a spolupráca. V roku 1950 sa Vojvoda z Edinburghu stáva patrónom organizácie Outward Bound. Za významný považujeme rok 1965, kedy vznikla Národná škola pre outdoorové vzdelávania; založil ju Paul Petzold v Spojených štátoch Amerických. V roku 1977 vznikla Wilderness Education Association (Wea, 2019) zameraná na školenie vedenia outdoorového vzdelávania. Dôležitým míl'nikom je vznik organizácie Outward Bound International v roku 1983, ktorá je zameraná na podporu medzinárodnej siete škôl Outward Bound. V roku 1989 bola obnovená činnost' Českého junáka - zväzu skautov a skautiek, ktoré bolo z politických dôvodov prerušené (Neuman et al., 2000). Outdoorová edukácia sa čím d’alej, tým viac uplatňuje vo vzdelávacích systémoch vyspelých krajín i v súčasnosti. Je jedným z progresívnych edukačných trendov 21 . storočia.

\section{Teoretické východiská predmetnej problematiky}

Outdoorová edukácia je výchova v prírode, ktorá využíva činnosti realizované najmä v prírodnom prostredí, zamerané na prípravu pre život v prírode. Snaží sa nájst' spôsob ako preniest' učebné a výchovné postupy do prírody, na získanie nových vedomostí o prírode a taktiež na vytvárania vztahu medzi človekom a prírodou (Neuman et al., 2000). V rámci tejto štúdie budeme používat' najmä pojem outdoorová edukácia, ktorý bližšie popisuje a charakterizuje aktívnu edukáciu vo vonkajšom prostredí. Outdoorovú edukáciu v zahraničí definujú aj ako akademickú disciplínu, vyučovaciu metódu, či postup vo výchovno-vzdelávacom procese, ktorý sa realizuje prostredníctvom zážitkového vyučovania (Nicol, 2002). Autori sa teda zhodujú, že v najširšom zmysle slova je označovaná ako vzdelávanie o „vonkajšku“ a jeho dôsledkoch. 
Jedná sa o vzdelávanie v prírode, pri ktorom sa rozvíja poznanie, zručnosti a postoje o svete. Žiaci prežívajú radost' z možnosti byt' vo vonkajšom prostredí a objavujú svet. Na tomto mieste môžu byt' zvedaví a aktívni. Môžu sa sústredit' a vykonávat' aktivity, ktoré si sami vyberú. To následne podporuje rozvoj pozitívnych postojov smerom k novým príležitostiam, výzvam a zodpovednostiam. Jedinečnost' outdoorového vzdelávania prináša možnost' zažit' krásu, radost', potešenie aj preniest' zázrak a čaro do každodenného života žiakov v školskom prostredí. Všeobecné základné ciele outdoorovej edukácie sú: naučit' sa, ako prekonat' nepriazeň, zlepšit' spoločenský a osobnostný rozvoj a rozvíjat' hlbší vzt’ah s prírodou. Outdoorová edukácia obsahuje tri oblasti: svet seba, svet l'udí a svet prírody. Každá z týchto oblastí sa rozvíja rôznymi spôsobmi. Medzi ciele týchto oblastí patrí: získat' zručnosti na prežitie v prírode, zlepšit' schopnost' riešenia problémov, posilnit' tímovú spoluprácu, znížit' recidívu, rozvíjat' vodcovské schopnosti, pochopit’ prírodné prostredie a podporovat' duchovnost' (Kudryavtsev et al., 2012). V našom ponímaní je outdoorová edukácia postup vo vzdelávaní, ktorý sa realizuje vo vonkajšom prostredí a zahrňuje tak pobyt v prírode rovnako ako využívanie prvkov miestneho regiónu. Môžeme teda povedat', že outdoorová edukácia je každá činnost', ktorá sa realizuje za dverami triedy vo vonkajšom prostredí. Výchova v prírode je proces zážitkového učenia prostredníctvom praktických činnosti, ktorý sa uskutočňuje v prírodnom prostredí. Pri takomto učení sa hlavný dôraz kladie na vztahy k l'udom a prírodnému prostrediu. Kvalita zážitku s pobytom v prírode je najlepšia, autentická, zmysluplná a dôležitá pre život. Tento prístup pozitívne vplýva na žiaka a jeho osobnost' v rozličných smeroch. Vo všeobecnosti môžeme sledovat' dva smery: dobrodružnú a ekologickú výchovu. Do dobrodružnej výchovy patria okrem aktivít v prírode aj intrapersonálne a interpersonálne vztahy. Tento smer sa uskutočňuje prostredníctvom úspešného prekonávania výziev v prírode a v umelom prostredí. Ďalším smer, ktorý výchova v prírode ponúka, je ekologická výchova, ktorá sa realizuje prostredníctvom jednotlivých ekologických programov, ktoré sa zameriavajú na vztahy medzi l'ud'mi a prírodným prostredím (Neuman et al., 2000; Neuman, 2004). Rôznorodé prepojenia výchovy a prírody umožňujú vnímat' vzájomnú väzbu v širokých významových rozdieloch. Identifikujeme tu výchovu pre prírodu, ktorá sa zameriava na problematiku poznávania vztahov medzi človekom a prírodným prostredím, a zároveň má na zreteli ochranu prírodného prostredia. Výchova o prírode sa zameriava na vzdelávací aspekt, kde prevláda získavanie poznatkov prostredníctvom 
vyučovacích predmetov ako prírodoveda, či prvouka v školskom prostredí. Ďalším významným pojmom je výchova prírodou, kde prírodné prostredie nie je len akousi kulisou alebo miestom výchovného pôsobenia, ale aj samonosným pedagogickým činitelom. Výchova v prírode je najpoužívanejším pojmom, ktorý vníma prírodu ako prostredie pre výchovný proces a zároveň označuje súbor popisovaných pedagogických disciplín. Výchova v prírode sa ako tradičné a historické pomenovanie stáva východiskom pre d’alšie pedagogické smery ako napríklad samotná zážitková pedagogika (Jirásek, 2004). Aktivita žiaka je základom pre interaktívne, skúsenostné a autentické učenie. Toto učenie je spojené s vlastným emocionálnym vnímaním a prežívaním, kedy hovoríme o zážitkovom učení. Ak hovoríme o zážitkovom učení, spája sa s Kolbovým cyklom učenia alebo experiential learning model, ktorý prepája subjektívny význam (vnútorný život žiaka) a objektívny význam (prostredie žiaka); čiže spája zážitok a skúsenost'. Tento model popisuje 4 fázy, ktorými prechádza žiak. Na začiatku je konkrétna skúsenost', kedy sa aktívne prežíva určitá činnost'. Následne prebieha reflexívne pozorovanie, pri ktorom žiaci rozmýšlajú o tom, čo sa stalo. Nasleduje abstraktné zovšeobecnenie, kedy žiaci vytvárajú určité teórie o tom, ako daný zážitok súvisí s predchádzajúcimi skúsenostami. V poslednej fáze sa musí zrealizovat' aktívne experimentovanie a to v podobe novej, práve vzniknutej teórie (Fedorko, 2020; Kolb, 1948). Experiential education, alebo výchovu skúsenostou a zážitkom, označujeme ako protipól teoretickým prístupom, pretože tento prístup stavia na piedestál najmä zážitky a skúsenosti, ktoré sa vytvárajú v zážitkovom prostredí. Toto prostredie je plné podnetov s rozličnými netradičnými metódami (Neuman et al., 2000). Jirásek (2004) pod definíciou zážitkovej pedagogiky rozumie teoretické spracovanie a analýzu takých výchovných procesov, ktoré pracujú s navodzovaním, rozborom a reflexiou prežitých udalostí za účelom vytvárania skúseností, ktoré je možné preniest' do d’alšieho života. Ciel' týchto výchovných procesov môžeme dosahovat' v rôznorodom prostredí: školskom, mimoškolskom, prírodnom a kultúrnom. Tieto výchovné procesy môžu byt' realizované prostredníctvom špecifických prostriedkov ako sú hry, modelové situácie, tvorivé dielne, diskusie a iné. Outdoorová edukácia prebieha na základe využívania špecifických metód a postupov. Detská hra a učenie sú v outdoorovej edukácií základom, toto učenie je v prírodnom prostredí posilnené, ked’že je bohato zásobené zaujímavými zdrojmi, ktoré sú prispôsobitel'né a dajú sa použit' rôznymi spôsobmi, podla individuálnych potrieb a záujmov žiakov. Hra sprostredkúva prostredie pre aktívne učenie, 
v ktorom má učiaci sa plnú slobodu pri svojom správaní a objavovaní nových súvislostí. Hra vytvára bezpečné prostredie, v ktorom sú žiaci chránení pred dôsledkami svojho správania (Neuman et al., 2000). Jednou z významných stratégií je práve place-based education; označujeme ju ako vzdelávanie založené na miestnom kontexte. Sobel (2005) ju opisuje ako vzdelávanie, pre ktoré je vel'mi dôležitá komunita a lokálne prostredie je najpodstatnejší bod vo výučbe jednotlivých konceptov vo všetkých predmetoch v rámci učebných osnov. Avšak vel'mi podstatným prvkom v tomto vzdelávaní sú takzvané hands on aktivity a získavanie skúseností z učenia sa v reálnom svete. Cielom place-based education je zameriavat' učenie na miesto, ktoré žiaci vel'mi dobre poznajú, čo ich vedie k väčšej aktivite. Takisto sa tento prístup snaží smerovat' ku konaniu dobra pre miestnu komunitu a miestne prostredie. Tento prístup edukácie sa snaží rešpektovat' žiaka ako intelektuálnu, duchovnú, emocionálnu a morálnu osobnost', ktorá hl'adá význam a zmysel svojej práce. Pre tento typ edukácie je typická skupinová práca postavená na kolaborácii medzi žiakmi a na individuálnej bádatel'skej činnosti tzv. hands on poznávanie a skúmanie okolitého prostredia. Tento prístup ku vzdelávaniu taktiež podporuje medzipredmetové vztáahy (Butt, 2011). Bádatel'ské aktivity využívame aj v outdoorovej edukácii, ked'že pri týchto aktivitách sa žiaci stávajú bádatelia a vedci. Takýmto spôsobom žiakom prinášame nielen potešenie, no zároveň zapájame do procesu ich kognitívne, afektívne a psychomotorické schopnosti (Kariková, 2007).

\section{Outward Bound prístup}

Organizácia Outward Bound je založená na vzdelávacom prístupe, kedy je vonkajšie prostredie vnímané ako trieda. Pozitívny výsledok v podobe skúseností žiakov na základnej škole, strednej, alebo vysokej škole je preukázaný vo forme zvyšovania vnímania seba samého, rešpektovania vzájomnej závislosti jednotlivcov a túžbe pozitívne zmenit’ svoje vlastné životy a životy ostatných. Prostredníctvom spoločných výziev, nepriazni osudu, neúspechu a úspechu žiaci objavujú a rozvíjajú nové zručnosti, sebadôveru a vášeň. Myšlienka, že „ste potrební“, bez ohl'adu na to, kto ste, je rozhodujúcou ingredienciou pre úspech programov Outward Bound (Outward Bound, 2021). Význam tejto organizácie vyzdvihuje aj odborník na predmetnú problematiku J. Neuman, ktorý vo svojej monografii Turistika a sporty v př́rodě (Neuman et al., 2000) venuje pozornost' tejto organizácii. A to nielen pre jej atraktívnost', ale najmä preto, že jej zakladatel' Kurt Hahn a d'alší jeho nástupníci výrazne 
ovplyvnili outdoorovú edukáciu. Vytvorili základy výchovy, ktorá využíva zážitok a dobrodružstvo. Úspechy, ktoré získali, zaujali množstvo odborníkov, ktorí sa následne tejto téme začali venovat' (Neuman et al., 2000). Kurt Hahn vychádzal z tvrdenia, že je v nás viac, než si sami myslíme. Ak sa nám podarí si to uvedomit', možno sa po zvyšok našich životov už neuspokojíme s ničím menším. V súčasnosti je Outward Bound International medzinárodná nezisková organizácia zastrešujúca Outward Bound školy vo viac ako 35 krajinách na 6 kontinentoch, ktoré zodpovedajú za kvalitu mena Outward Bound vo svete. Všetky Outward Bound pobočky prechádzajú pravidelným procesom obnovenia licencie a využívajú špecifický vzdelávací model Outward Bound. Ich cielom je zameriavat' sa na rozvoj osobnosti a sociálnych zručností účastníkov, využívajúc pri tom metódy zážitkového a outdoorového vzdelávania (Outward Bound, 2021).

\section{Analýza outdoorovej edukácie vo vybraných štátoch}

V tejto kapitole budeme venovat' pozornost' komparatívnej analýze outdoorovej edukácie vo vybraných krajinách, ktoré sú súčast'ou organizácie Outward Bound International. Táto organizácia zastrešuje 35 štátov. Výber jednotlivých krajín bol zámerný na základe zvolených kritérií: dlhodobá tradícia, historický kontext, realizácia outdoorovej edukácie na všetkých stupňoch vzdelávacie systému a realizácia outdoorovej edukácie $\mathrm{v}$ súčasnosti. Vybrali sme štáty, ktoré majú dlhodobú tradíciu v oblasti outdoorovej edukácie a ich vznik sa datuje už od začiatku 19. storočia. Ide o krajiny Nový Zéland, Kanada, Nórsko, Škótsko a Anglicko. V rámci komparácie sme sa samozrejme zamerali aj na naše územie, kde sme pristúpili k analýze outdoorovej edukácie v Českej republike a na Slovensku.

\subsection{Metodologie}

Výskumný problém

Definícia výskumného problému znie: Aké sú spoločné a odlišné znaky outdoorovej edukácie vo vybraných krajinách zapojených do organizácie Outward Bound Intenational? 


\section{Ciel' štúdie}

Hlavným cielom predkladanej štúdie je zistit' spoločné a odlišné znaky outdoorovej edukácie vo vybraných krajinách zapojených do organizácie Outward Bound Intenational.

Hlavný ciel' bol rozčlenený do dvoch čiastkových cielov:

1) Teoreticky spracovat' históriu a súčasnost' outdoorovej edukácie vo vybraných krajinách.

2) Analyzovat' a porovnat' jednotlivé atribúty realizácie outdoorovej edukácie vo vybraných krajinách.

\section{Použité metódy}

Využité boli najmä literárne metódy, kvalitatívna analýza teoretických zdrojových prameňov a literárnych zdrojov, vybraných štúdii a výskumov, ktoré predstavujú realizáciu outdoorovej edukácie a pomocou metódy otvoreného kódovania sme spracovali konceptuálnu základňu realizácie outdoorovej edukácie. Na základe štátnych vzdelávacích dokumentov, školských zákonov a monografii sme doplnili informácie, ktoré sa zameriavali na realizáciu outdoorovej edukácie.

\section{Postup pri spracovaní prehladovej štúdie / analýza dát}

Pre vyhladávanie výskumných štúdii na našom území sme stanovili klúčové slová (outdoorová edukácie, zážitkové vzdelávanie, výučba za dverami triedy, vonkajšie prostredie). Vyhladávané boli články, v ktorých sa objavilo jedno či viac klúčových slov. Pri zmapovaní zahraničných štúdii sme si stanovili klúčové slová (outdoor education, experiential education in nature, learning outside the classroom, external environment). Taktiež sme sa zamerali na výskumy a články, v ktorých sa objavilo jedno alebo viac klúčových slov. Pre účely výskumného zamerania práce, ktorá je postavená na sprostredkovanom zist'ovaní realizácie outdoorovej edukácie, sme využili plno-textové databázy z EZ - Proxy, ktorá umožňuje vzdialený prístup do externých elektronických zdrojov. Pracovali sme so zahraničnými databázami: Proquest, Scopus, Web of science, Nature Publishing, EBSCO a Scientific American. V rámci kritéria spôsobilosti sme vyhladávali všetky typy štúdií (napr. dizajn kontrolnej skupiny, kvázi experimentálny dizajn a prípadové štúdie). Kvôli vel'kému počtu zdrojov sme sa zamerali len na databázy Scopus, Web of Science a Nature Publishing, kde sme pracovali len s full textovými štúdiami. 


\section{Tabul'ka 1}

Vývojový diagram vyhladávania v plno-textových databázach

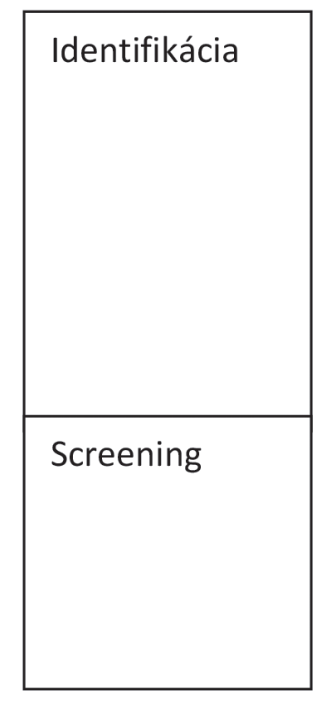

Databáze: Proquest, Scopus, Web of science, Nature Publishing, EBSCO, Scientific American.

Scopus, Web of science a Nature Publishing

Prostredníctvom databáz bolo nájdených 8504 textov

Relevantné na základe názvu: 756 textov

Relevantné na základe kl'účových slov: 78 textov

Spôsobilost'

Full- textové štúdie a výskumy

Formálne vzdelávanie: vzdelávacie kurikulá, vzdelávacie osnovy a štandardy, školské zákony. Neformálne vzdelávanie: občianske združenia, neziskové organizácie

Zhrnutie

Použitých štúdií a výskumov: 14

Použitých literárnych prameňov: 8

Zvolené kategórie komparatívnej analýzy vybraných krajín

- Formálne vzdelávanie.

- Neformálne vzdelávanie.

- Zapojenie do Outward Bound International.

- Národné kurikulum.

- Výchova skúsenostou a zážitkom. 
- Komplexný rozvoj osobnosti.

- Rozvoj environmentálnej gramotnosti.

Na základe týchto 7 základných kritérií sme realizovali komparatívnu analýzu outdoorovej edukácie vo vybraných krajinách. Zvolené kritéria vychádzali z obsahu a formy outdoorovej edukácie. Za najvýznamnejšie kritérium sme zvolili realizáciu outdoorovej edukácie vo formálnom vzdelávaní, ked'že smerovanie nášho výskumu $\mathrm{v}$ rámci dizertačnej práce sa venuje primárnemu stupňu vzdelávania. Ďalej sme sa zamerali na neformálne vzdelávanie, pretože outdoorová edukácia vytvára značný priestor aj pre neformálne vzdelávanie. Ďalším kritériom je zapojenie outdoorovej edukácie do národného kurikula danej krajiny. Pre kritérium komplexný rozvoj osobnosti sme sa zamerali na jednotlivé oblasti, na ktoré kladú vybrané štáty dôraz. Zarad'ujeme tam rozvoj kognitívnej, psychomotorickej a afektívnej oblasti osobnosti. Vzhladom na stúpajúci význam environmentálnej gramotnosti sme toto kritérium zaradili do komparatívnej analýzy ako samostatné.

\section{Výber krajín}

Výber krajín prebiehal podla vopred určených kritérií: jazykové hl'adisko (informácie dostupné v českom, slovenskom nebo anglickom jazyku), kultúrny náhl'ad, historický kontext a geografické hladisko. Vybrali sme štáty, ktoré majú dlhodobú tradíciu v oblasti outdoorovej edukácie a vznik sa datuje už od začiatku 19. storočia. Ide o krajiny ako Nový Zéland, Kanada, Nórsko, Škótsko, Anglicko, v neposlednom rade sme sa zamerali na naše územie, kde sme sa rozhodli analyzovat’ Českú republiku a Slovensko.

\subsection{Nový Zéland}

Outdoorová edukácia je súčastou vzdelávania na Novom Zélande už viac ako 150 rokov. Vzdelávací systém Nového Zélandu bol vytvorený na základe britského koloniálneho zákona. Outdoorová edukácia sa postupom času menila hlavne pod vplyvom zmien v edukačnom systéme tejto krajiny. Spočiatku bola outdoorová edukácia chápaná viac ako rekreačná činnost', no postupne bola zarad’ovaná do systému formálneho vzdelávania. V roku 1970 sa začala výučba outdoorovej edukácie v prírode presadzovat' ako proces získavania zručnosti a hodnôt zameraných na budúce povolanie. Už v roku 1999 bolo vytvorené obsiahle národné kurikulum, ktorého súčast'ou bol aj dokument, ktorý si každá škola vytvára sama. Ide vlastne o individuálne školské vzdelávacie 
programy. Outdoorová edukácia je v štátnych vzdelávacích dokumentoch zahrnutá v v predmetoch prírodoveda, sociálne štúdiá, environmentálne vzdelávanie a technológia. Výraznejšie postavenie má v predmetoch zdravotné vzdelávanie a telesná výchova. Ciele zahŕňajú prostredníctvom outdoorového vzdelávania v telesnej a zdravotnej výchove vybudovat' u žiakov vedomosti, zručnosti, schopnosti, hodnoty a motivovat' žiakov robit’ také rozhodnutia, ktoré prispievajú $\mathrm{k}$ ich osobnému blahu, blahobytu ostatných l'udí a potom aj spoločnosti ako celku. To je možno považovat' za splnenie jedného nami stanovených kritérií, a to komplexného rozvoj osobnosti žiaka. Učebné osnovy týchto predmetov sú rozdelené do siedmich klúčových výučbových oblastí: duševné zdravie, sexuálna výchova, životospráva, starostlivost' o telo, fyzická bezpečnost', fyzická aktivita, športové aktivity a výučba v prírode. Konkrétne ciele oblasti výučby majú poskytovat' študentom príležitosti na rozvoj osobných a sociálnych zručností, aby sa žiaci stali aktívnymi, schopnými fungovat' vo vonkajšom prostredí a aby dbali na ochranu a starostlivost' o životné prostredie. Tým je naplnené naše kritérium rozvoj environmentálnej gramotnosti (Kane \& Tucker, 2007; Kime, 2008; Zink \& Boyes, 2006). Robyn Zink z Monash University a Michael Boyesz University of Otagoonku (2006) sbierali dáta na 147 základných školách pomocou dotazníku, ktorý sa zameriaval na podporu výučby outdoorovej edukácie počas celého výučbového procesu. Učitelia realizovali outdoorovú edukáciu v predmetoch telesná a zdravotná výchova, d’alej nasledovala prírodoveda, sociálne štúdie a najmenej využívali outdoorovú edukáciu v predmetoch ako umenie, technológie a matematika. Respondenti boli požiadaní, aby uviedli aktivity, ktoré realizovali so žiakmi. Uviedli aktivity ako lezenie, tramping, kemping, horolezectvo a plachtenie. Ďalej zmienili botanické záhrady, farmy, hory, skalnaté pobrežie a mokrade, boli spomenuté rôzne mestá okolo Nového Zélandu, hvezdárne, umelecké galérie a múzeá. Nový Zéland je známy ako miesto dobrodružstva. Túto predstavu umocňujú aj jednotlivci, ktorí získali svetové uznanie v netradičných outdoorových aktivitách, napr. Sir Edmund Hillary, Paul Caffyn a d’alší.

\subsection{Kanada}

Štruktúra vzdelávacieho systému v Kanade je úzko spätá s Vel'kou Britániou. Prvý zdokumentovaný program Outdoorovej edukácie v Kanade bol Big Cove Young Camp Men's Christian Association (https://www.ymca.ca/) $\mathrm{v}$ roku 1889. Tento tábor poskytoval biblické, študijné a rekreačné aktivity pre deti a mládež, aby rástli na duchu, mysli a tele. Tento program ovplyvnil 
Sir George Williams, ktorý chcel poskytnút' alternatívu k nezdravému životnému štýlu, ktorému boli deti a mládež vystavení pri migrácii. Rovnako tak skautské hnutie, ktoré vzniklo v Británii, sa stalo populárnym aj v Kanade začiatkom 20. rokov 20. storočia. Dialo sa tak pomocou outdoorových aktivít zameraných na rozvoj morálnej a fyzickej oblasti, a to prostredníctvom neformálneho vzdelávania. Outdoorová edukácia bola postupne zapojená do vzdelávacieho systému prostredníctvom zapojenia do národného kurikula najprv v roku 1950 a neskôr výraznejšie v 1980 (Kime, 2008). Purc-Stephenson a kol. z University of Alberta (2019) si dali otázku, či existujú špecifické kanadské spôsoby ako realizovat' outdoorovú edukáciu. Na základe ich výskumu zistili, že existujú, a nazvali ich „prieskumníkmi divočiny“. V mnohých ohladoch sa outdoorová edukácia $\mathrm{v}$ Kanade aj v súčasnosti pokúša znovu vytvorit' priestor prostredníctvom zážitkových aktivít a skúsenosti pre prieskumníkov, ktorí sa stretávajú a musia prekonávat' rôzne situácie v prírodnom prostredí, bez vymožeností súčasnosti. Slovo „prieskumníci“ označuje túžbu cestovat' s ostatnými, naučit' sa a objavit’ niečo nové. Divočinu chápu ako miesto, ktoré označuje nepoznané miesta vo vonkajšom prostredí.

\subsection{Nórsko}

Nórske friluftsliv $\mathrm{v}$ doslovnom preklade znamená život vonku, ktorým označuje spôsob prežívania prírody. Tento pojem prepája primárny význam, teda outdoorovú edukáciu, a sekundárny význam, isté kvality prepojené so skúsenostou žit' vo vonkajšom prostredí z filozofického pohl'adu. Existujú minimálne 3 prístupy, ako v Nórsku rozdelujú modernú výučbu: pedagogika pre friluftsliv, pedagogika s friluftsliv a pedagogika cez friluftsliv. Pedagogika pre friluftsliv sa objavuje na školách, školách v prírode a na vysokých školách a je inšpirovaná environmentálnou výchovou. Základný ideál zážitkovej pedagogiky sa zameriava na učenia pomocou skúseností a reflexie. Hlavným princípom pedagogiky pre friluftsliv je vytvárat' priestor pre žiakov k vlastnému rozhodovaniu sa o trase alebo aktivite, a to na základe kompetencie účastníkov. Osvojenie si schopností potrebných pre zvolenú činnost' je absolútnou nevyhnutnostou. Je teda efektívnejšie začat's l'ahkými úlohami a neskôr postupovat' k zložitým. Koncom 20. storočia sa práve zážitkové učenie ukázalo ako vhodný spôsob, ktorý bol realizovaný najmä prostredníctvom školy v prírode na nórskych základných školách. Termín Uteskole alebo škola v prírode označuje pedagogický prístup k prírode. Škola v prírode je spôsob práce so školou. Žiaci a učitelia využívajú blízke okolie a miestne komunity ako 
zdroj vo formálnom vzdelávaní. Pojem uteskole zahŕňa pravidelné a cielené aktivity mimo triedu. Táto relatívne nová tradícia zahŕňa celý rad praktických, estetických a tvorivých prístupov k učeniu vrátane interdisciplinarity, používania hry, hrania rolí a dramaturgických prístupov realizovaných najmä v neformálnom vzdelávaní. Friluftsliv obsahuje bohatstvo pozitívnych emócií. Školský obsah a osnovy využívané v outdooroveje edukácii majú pozitívny vplyv na fyzické aktivity, mentálne zdravie, vzdelávacie výsledky a sociálne kompetencie (Becker, 2017; Parry \& Allison, 2020). Je to jedna z ciest pozitívneho pôsobenia na komplexný rozvoj osobnosti.

\section{5 Škótsko}

Aj ked' je Škótsko súčast'ou Spojeného královstva, má odlišnú kultúrnu identitu a samostatný vzdelávací a právny systém. Škótsko bola jednou z prvých krajín na svete, ktorá formálne uplatňovala outdoorové vzdelávanie. Bolo to výsledkom kombinácie viacerých faktorov. Geofyzikálne a klimatické faktory spolu s postupmi zadržiavania pôdy a využívania pôdy ustanovené v 18. storočí zabezpečili, že vel'ká čast' škótskej vysočiny je vyludnená a bez lesov, čo vedie k vnímaniu, že oblast' je „divočina“, preto je atraktívna pre rekreáciu v prírode. V 60. a 70. rokoch sa v Škótsku intenzívne rozvíjalo vzdelávanie v prírode, často $\mathrm{v}$ podobe fyzických outdoorových aktivít (Higgins, 2007, 2009). V roku 2010 vládna vzdelávacia poradná agentúra vydala dokument s názvom Curriculum for Excellence, ktorá konkrétne prepojila učebné osnovy respektíve formálne vzdelávanie s outdoorovým učením a s dôrazom na jeho edukačný potenciál. Mnoho škótskych mimovládnych organizácií, ako napríklad Grounds for Learning, Eco-Schools a John Muir Trust, a vládne agentúry ako Škótske prírodné dedičstvo, Lesnícka komisia, Škótske národné parky a Sport Scotland podporili outdoorovú edukáciu na školách, na národnej, regionálnej a medzinárodnej úrovni. Učenie mimo učebne sa môže uskutočňovat' v školskom areáli alebo na mikroregionálnej úrovni a môže sa zamerat' na celý rad vzdelávacích oblastí: podporu životného prostredia, osobnostný rozvoj a fyzickú aktivitu. Stále pribúdajú dôkazy o tom, že existuje vzt’ah medzi zeleným priestorom ako sú mestské parky, otvorená krajina, lesy, pobrežie a zdravím, respektíve pohodou. Učenie vonku kontrastuje s učebňou, pretože prostredie je ovplyvňované počasím, ročnými obdobiami a časom. Krajina a pobrežné oblasti Škótska sú dôležité pre pochopenie histórie, kultúry a prírodného dedičstva. Škótska vláda v roku 2014 prijala 31 odporúčaní správy Learning for Sustainability, ktorú pripravila pracovná skupina škôl One Planet, vrátane toho, že vonkajšie vzdelávanie by malo byt' 
pravidelnou skúsenost'ou realizovanou cez učebné osnovy pre všetkých žiakov. Každý žiak by mal mat' možnost' každodenného kontaktu s prírodou, pre vonkajšie vzdelávanie a hru (Hepburn, 2014).

\subsection{Anglicko}

Outdoorová edukácie v Anglicku má dlhú históriu od 40. rokov 20. storočia (Nicol, 2002), ktorá je často spájaná Kurtom Hahnom, Gordonstoun School či organizáciou Outward Bound. Ak chceme pochopit' posledných dvadsat' rokov outdoorového vzdelávania v národných učebných osnovách Anglicka, je potrebné uvedomit' si kultúru a význam výučby v prírode v tejto krajine. Zákon o reforme školstva (ERA) z roku 1988 bol významnou udalost'ou v reforme obsahu vzdelávacieho systému v Anglicku. Formalizovali sa národné učebné osnovy a vytvorili učebné osnovy pre žiakov vo veku od 5 do 16 rokov. Bol zdôraznený význam skúseností s výučbou v prírode a vymedzený prostredníctvom prierezovej témy. Národná asociácia pre outdoorové vzdelávanie (NAOE) vytvorila teoretické základy outdoorovej edukácie. V roku 1970 bola výučba v prírode nástrojom ako dosiahnut' vzdelávacie ciele prostredníctvom riadených priamych skúseností a učebných materiálov vo vonkajšom prostredí. Využívané boli najmä v predmetoch geografia, dejiny, umenie, terénna biológia, environmentalistika a telesná výchova. $\mathrm{V}$ roku 2006 bol vytvorený Outdoor manifest, Za dverami triedy, ktorý zdôrazňoval implementáciu vonkajšieho vzdelávania do školských osnov (Leather, 2018). Výskum Every experience matters sa zameriava na význam outdoorovej edukácie a jej pozitívny vplyv na komplexný rozvoj osobnosti žiakov. V rámci tohto výskumu boli spracované štúdie zamerané na outdoorové vzdelávanie na území Vel'kej Británie a Spojených štátov. Z týchto štúdii vyplynulo, že žiaci, ktorí boli zapojení do outdoorového vzdelávania, mali vyššiu úroveň fyzických a motorických zručností. Progres u žiakov bol viditelný aj v oblasti sebahodnotenia, sebaúcty, sociálnych kompetencií a environmentálnej gramotnosti (Malone, 2008). Špecifickou outdoorovou aktivitou, ktorá je realizovaná v neformálnom vzdelávaní najmä v Anglicku, no v súčasnosti už aj d’alších krajinách, je Medzinárodná cena vojvodu z Edinburghu, skrátene DofE, ktorá je zastrešovaná Vojvodom z Edinburghu. Predstavuje komplexný rozvojový program, ktorý dáva mladým lud’om vo veku 14 až 24 rokov šancu rozvinút' svoje schopnosti a charakterové vlastnosti pre reálny život. Buduje vztahah k prírode a k udržatelnému životnému štýlu. Taktiež si kladie za ciel' učit' mladých l'udí tak, aby dokázali naplnit' svoj potenciál a uspiet' v dalšom živote (Allison \& Telford, 2005). 


\section{7 Česká Republika}

Rozvoj outdoorovej edukácie $\mathrm{v}$ Českej republike siaha až do dôb J. A. Komenského, ktorý sa už v roku 1492 snažil začlenit' cestovanie a pobyt v prírode do výchovy mládeže. Rok 1862 je spájaný s prvým sokolským výletom, kde sa zameriavali na precvičovanie chôdze a prekonávanie prírodných prekážok. Nemenej dôležitým je obdobie rokov 1912-1914, kedy sa vytvárajú prvé oddiely skautov. Na území Československa sa outdoorová edukácia formovala od roku 1911 pod vedením Antonina Benjamína Svojsíka (Neuman et al., 2000). Outdoorová edukácia bola taktiež ovplyvnená skautom a spisovatel'om Jaroslavom Foglárom. Jeho odkaz zahŕňa myšlienky romantiky, odvahy a mystickosti a taktiež transformuje vzdelávanie na samovzdelávanie. Typická outdoorová aktivita $\mathrm{v}$ prostredí českej prírody je tramp. Označujeme ho ako vol'nočasovú aktivitu v prírode, kde sa účastníci pohybujú a prespávajú vo vol'nej prírode. Pravou legendou v oblasti outdoorovej edukácie bol projekt Gymnasion, ktorý sa pokúšal objavit’ nové formy vonkajšieho vzdelávania v prírodnom prostredí. Cielom bolo zmenit' aktivity v prírode na vzdelávanie v prírode (Parry \& Allison, 2020). Dôležitým míl'nikom pri rozvoji outdoorovej edukácie v Českej republike je obdobie od 1964-1974, kedy bola usporiadaná prvá Tábornícka škola, so snahou vytvorit' prítažlivejšie prostredie pre mladú generáciu. Rok 1974 je známy najmä vznikom Hnutia Brontosaurus, ktoré pomáhalo pri rozvoji ekologickej výchovy na území Českej republiky (Neuman et al., 2000). Jedným z fenoménov Českej republiky je Prázdninová škola Lipnice. Cielom jej zriad’ovatelov a propagátorov je tvorba kurzov, ktoré pomáhajú l'ud'om objavovat' a rozvíjat' vlastný potenciál, odvahu a tvorivost'. Už viac ako 40 rokov vytvárajú jedinečnú metódu zážitkovej pedagogiky, ktorú ponúkajú širokej verejnosti, školám a neziskovým organizáciám. Ich snahou je predstavit' učenie, ktoré môže byt' iné a zábavné. Predstavuje tak realizáciu neformálneho vzdelávania v Českej republike. V roku 2019 vyšla publikácia Koncepce terénni výuky pro základní školy (Svobodová et al., 2019), ktorá vychádza z dlhoročných skúseností z realizácie outdoorového vzdelávania na Katedre geografie MU v Brne. Zámerom tohto materiálu je metodicky podporit' učitelov v ich snahe o zarad'ovanie predovšetkým krátkodobých a strednodobých foriem terénnej výuky na základných a stredných školách. Metodika bola certifikovaná Národným ústavom pre vzdelávanie. Vel'ký počet rodičov sa v dnešnej dobe aktívne zaujíma o vzdelávanie svojich detí a rôzne materské školy s alternatívnymi pedagogickými prístupmi. $\mathrm{V}$ Českej republike je vytvorených $\mathrm{v}$ rámci 
predprimárneho vzdelávania už viac ako 40 lesných materských škôl, čo môžeme označitźza stúpajúcu tendenciu. Česká republika tak spíňa kritérium formálneho vzdelávania v podobe budovania lesných materských škôl. Podla Neumana a kol. (2018) oblast' outdoorového zážitkového vzdelávania stále trpí kultúrnymi nedostatkami týkajúcimi sa terminológie pojmov anglických a neanglických. Preto existuje potreba spoločného medzikultúrneho (jazykového) výskumu, ktorý umožní lepšie pochopenie týchto kontextovo špecifických rozdielov a perspektív Vd’aka tomu by sa mohol zlepšit' výskum, výučba a vedenie v oblasti outdoorovej edukácie.

\subsection{Slovenská republika}

Aj ked' Slovensko v realizácii outdoorovej edukácie nepatrí medzi krajiny $\mathrm{s}$ najdlhšou históriou, $\mathrm{v}$ období posledných dvoch až troch dekád zaznamenávame i v tejto oblasti zvýšenú dynamiku pozitívnych zmien. Podpora outdoorového vzdelávania prebieha prostredníctvom projektov, ktoré prinášajú materiálnu, finančnú a vzdelávaciu pomoc. Vyberáme len projekty, ktoré boli zrealizovane v rokoch 2012-2020. Realizujú sa prostredníctvom organizácii Akadémia Strom života a ich projektov Change the Grounds, Sombio, Nesed' bokom a angažuj sa pri riešení problémov životného prostredia (https://stromzivota.sk/). Ďalším prístupom vo vzdelávaní na našom území je lesná pedagogika, ktorá rozvíja prírodovednú a environmentálnu gramotnost'. Je zameraná na spoznávanie prírody, života v lese a objavovanie prírodných tajomstiev prostredníctvom hier a zážitkov. Koncepcia lesnej pedagogiky ako súčasti environmentálnej výchovy na Slovensku sa snaží zhodnotit' súčasný stav v oblasti lesnej pedagogiky doma i v zahraničí a následne vytýčit' d’alší smer rozvoja v nasledujúcom období. Návrh koncepcie sa opiera a nadväzuje na dôležité programové dokumenty Ministerstva pôdohospodárstva a rozvoja vidieka SR, Ministerstva životného prostredia SR a Ministerstva školstva SR. Neformálne vzdelávanie prebieha najmä prostredníctvom občianských združení a organizácií, ako napríklad Outdoor Institute Stageman, Klub Prieskumník-Pathfinder alebo už spomínaný Outward Bound ${ }^{1}$. Z hladiska zapojenia outdoorovej edukácie do národného kurikula, sledujeme tendenciu intenzívnejšieho využívania prierezových tém, konkrétne Environmentálnej výchovy, Regionálnej výchovy a ludovej kultúry a Ochrany života a zdravia. $V$ rámci inovovaného štátneho vzdelávacieho programu pre primárny stupeň vzdelávania sa outdoorová edukácia realizuje najčastejšie

1 http://www.pathfinder.sk/, http://www.outwardbound.sk/, http://outdoor-institute.sk/ 
vo vzdelávacích oblastiach Človek a príroda (predmet prírodoveda), Človek a spoločnost' (predmety prvouka a vlastiveda) a Zdravie a pohyb (predmet telesná a športová výchova; Štátny vzdelávací ústav, 2019).

\section{$5 \quad$ Interpretácia zistení a diskusia}

\section{Tabul'ka 1}

Porovnanie krajín

\begin{tabular}{lcclclcc}
\hline & $\begin{array}{l}\text { Formálne } \\
\text { vzdeláva- } \\
\text { nie }\end{array}$ & $\begin{array}{l}\text { Neformá- } \\
\text { lne vzde- } \\
\text { lávanie }\end{array}$ & $\begin{array}{l}\text { Národné } \\
\text { kuriku- } \\
\text { lum }\end{array}$ & $\begin{array}{l}\text { Zážitkové } \\
\text { vyučova- } \\
\text { nie }\end{array}$ & $\begin{array}{l}\text { Outward } \\
\text { Bound } \\
\text { Internati- } \\
\text { onal }\end{array}$ & $\begin{array}{l}\text { Komplex- } \\
\text { ný rozvoj } \\
\text { osobnosti }\end{array}$ & $\begin{array}{l}\text { Rozvoj } \\
\text { ronmen- } \\
\text { tálnej gra- } \\
\text { motnosti }\end{array}$ \\
\hline $\begin{array}{l}\text { Nový } \\
\text { Zéland }\end{array}$ & $\checkmark$ & $\checkmark$ & $\checkmark$ & & $\checkmark$ & $\checkmark$ & \\
\hline Kanada & $\checkmark$ & $\checkmark$ & $\checkmark$ & $\checkmark$ & $\checkmark$ & & $\checkmark$ \\
\hline Nórsko & $\checkmark$ & $\checkmark$ & $\checkmark$ & $\checkmark$ & $\checkmark$ & $\checkmark$ & $\checkmark$ \\
\hline Škótsko & $\checkmark$ & $\checkmark$ & $\checkmark$ & & $\checkmark$ & & $\checkmark$ \\
\hline Anglicko & $\checkmark$ & $\checkmark$ & $\checkmark$ & $\checkmark$ & $\checkmark$ & & $\checkmark$ \\
\hline $\begin{array}{l}\text { Česká } \\
\text { republika }\end{array}$ & $\checkmark$ & $\checkmark$ & & $\checkmark$ & $\checkmark$ & $\checkmark$ & $\checkmark$ \\
\hline Slovensko & $\checkmark$ & $\checkmark$ & $\checkmark$ & & $\checkmark$ & & $\checkmark$ \\
\hline
\end{tabular}

V tejto kapitole sa venujeme interpretácii výsledkov komparatívnych analýz outdoorovej edukácie vo vybraných krajinách zapojených do Outward Bound International. Každý z analyzovaných štátov má svoje špecifické poňatie realizácie outdoorovej edukácie. Tabul'ka 1 predstavuje stručný pohlad na špecifiká jednotlivých štátov prostredníctvom zdôrazňovania či uplatňovanie jednotlivých kritérií. Významným prvkom na Novom Zélande je prepojenie učebných osnov telesnej a zdravotnej výchovy, ktoré rozdelili do siedmich výučbových oblastí: duševné zdravie, sexuálna výchova, životospráva, starostlivost' o telo, fyzická bezpečnost', fyzická aktivita, športové aktivity a výučba v prírode. Ako dôležitý a inšpiratívny vnímame prístup Nového Zélandu zamerat' sa na konkrétne ciele v oblasti výučby outdoorovej edukácie, ktoré majú poskytovat' žiakom príležitosti na rozvoj osobných a sociálnych zručností, aby sa žiaci stali aktívnymi, schopnými fungovat' vo vonkajšom prostredí a aby dbali na ochranu a starostlivost' o životné prostredie v kontexte 
ochrany a zachovania zdravia. Možno konštatovat', že v krajinách ako Nový Zéland, Škótsko a Kanada sa využíva široká škála rôznorodých outdoorových aktivít: lezenie, tramping, kemping, horolezectvo a plachtenie. Všetky tieto štáty si uvedomujú rozličné bariéry, ktoré sa vyskytujú pri outdoorovej edukácii, no na zreteli majú najmä pozitívne aspekty outdoorovej edukácie na rozvoj osobnosti žiaka. Špecifiká krajín sme ukázali. V Kanade vidia cestu v podobe „prieskumníkov v divočine“; žiaci sa stretávajú v prírodnom prostredí a musia prekonávat' rôzne situácie, ktoré zažívajú v prírode. Škótsko ukazuje, že je možné aj konkrétne prepojenie učebných osnov s outdoorovým učením. Nórska cesta ide cez pedagogikou friluftsliv, kde prepájajú spôsob prežívania prírody na zmenu kvality skúseností a filozofie poznania. Analýza Nórskeho spôsobu outdoorovej edukácie nám pomáha uvedomit’ si, že učenie mimo učebne sa môže uskutočňovat' v školskom areáli alebo na okolí školy vo vonkajšom prostredí a môže sa zamerat' na celý rad vzdelávacích oblastí. Taktiež význam outdoorovej edukácie spočíva $v$ jej pozitívnom vplyve na žiakov v komplexnom rozvoji osobnosti, o ktorý sa snaží nie len Nórsko, ale aj ostatné krajiny spomenuté v tabul'ke. Záslužnou outdoorovou aktivitou, ktorú je potrebné vyzdvihnút', je Medzinárodná cena vojvodu z Edinburghu. V Anglicku táto činnost' (skrátene DofE) predstavuje komplexný rozvojový program, ktorý dáva mladým l'ud'om šancu rozvinút' svoje schopnosti a charakterové vlastnosti pre reálny život. Jedným z fenoménov Českej republiky je Prázdninová škola Lipnice. Tá realizuje kurzy, ktoré pomáhajú l'ud’om objavovat' a rozvinút' vlastný potenciál, odvahu a tvorivost', prostredníctvom zážitkovej pedagogiky, ktorú ponúkajú širokej verejnosti, školám a neziskovým organizáciám. V súčasnej dobe sa outdoorová edukácia rozvíja na Slovensku pomerne rýchlym tempom. Podpora outdoorového vzdelávania prebieha najmä prostredníctvom občianskych združení, neziskových organizácii a realizáciou projektov pod záštitou Ministerstva životného prostredia, ktoré podporujú materiálnu, finančnú a vzdelávaciu pomoc v oblasti outdoorovej edukácie. Vo všetkých analyzovaných krajinách vnímame trend zvýšeného záujmu o uplatňovanie outdoorovej edukácie v pedagogickej praxi, a to prostredníctvom formálneho, ako aj neformálneho vzdelávania.

\section{Záver}

Outdoorová edukácia sa v posledných dvoch decéniách výrazne presadzuje vo výchovno-vzdelávacích systémoch všetkých vyspelých krajín. Jej značný edukačný potenciál pri komplexnom rozvoji osobnosti žiaka je nepochybný, 
čo potvrdzujú aj mnohé skúsenosti a výsledky odborných štúdií. Spôsoby jej realizácie v jednotlivých krajinách sa však odlišujú. Vplýva na to viacero faktorov. Najčastejšie je to kultúra, filozofia, prostredie, mentalita, sociálne a materiálne podmienky. V poslednom období sa do popredia dostávajú otázky ochrany prírody a zachovanie trvalo udržatel'ného rozvoja, ked’že globálne environmentálne problémy začínajú ohrozovat' samotnú existenciu l'udstva na Zemi. Práve v prepojení environmentálnej výchovy a outdoorovej výchovy vidíme priestor na formovanie zmeny názorov, postojov a konania l'udí. Outdoorové prostredie je ideálne pre uplatňovanie medzipredmetových vztahov. Týka sa to všetkých predmetov, ako prírodovedných, tak spoločenskovedných, výchovných i umeleckých. Outdoorová edukácia ponúka žiakom všetko to, čo tradičné vzdelávanie v laviciach. Okrem toho poskytuje ovela vhodnejšie prostredie pre rozvoj takých schopností ako sú spolupráca, sebaregulácia, autoreflexia, snaha o dokončenie činností, vytrvalost', riešenie problémov, fyzická aktivita, pozorovanie a terénne práce. Diet’a sa prirodzene a spontánne učí pozorovaním okolitého sveta. Pre žiakov poskytuje reálny svet mimo triedu (školu) obrovské množstvo podnetov na poznávanie a zároveň je prirodzeným zdrojom aktivizácie a motivácie. Využívanie analýzy realizácie outdoorovej edukácie v krajinách, v ktorých je jej tradícia silnejšia, môže vo viacerých smeroch obohatit' edukačnú realitu výchovno-vzdelávacieho systému aj u nás. Pre d’alší rozvoj outdoorovej edukácie na Slovensku je potrebné vychádzat’ z medzinárodných skúseností, no nemožno ich aplikovat' bez hlbšieho vnímania historického kontextu edukačnej praxe u nás, teda tradícií a zvyklostí, spoločenských hodnotových rámcov, úrovne empírie, spoločenských a ekonomických podmienok uplatnitel'nosti koncepčných opatrení. Proces realizácie outdoorovej edukácie je náročný a plný rozličných bariér, avšak jeho vplyv na rozvoj osobnosti žiaka je nezastupitelný.

\section{Literatúra}

Becker, C., Lauterbach, G., Spengler, S., Dettweiler, U., \& Mess, F. (2017). Effects of regular classes in outdoor education settings: A systematic review on students' learning, social and health dimensions. International Journal of Environmental Research and Public Health, 14(5), 485-505.

Butt, G. (2011). Geography education and the future. Continuum.

Ford, P. (1986). Outdoor education: Definition and philosophy. ERIC/CRESS.

Allison, P., \& Telford, J. (2005). Turbulent times: Outdoor education in Great Britain 1993-2003. Australian Journal of Outdoor Education, 9(2), 21-30.

Fedorko, V. (2020). Outdoorová edukácia v materskej škole. Prešovská univerzita v Prešove. 
Higgins, P. (2007). Outdoor education in Scotland. Journal of Adventure Education and Outdoor Learning, 2(2), 149-168.

Higgins, P. (2009). Into the big wide world: Sustainable experiential education for the $21^{\text {st }}$ century. Journal of Experiential Education, 1(32), 44-60.

Hepburn, H. (2014). Curriculum-A field of dreams or out in the cold?. The Times Educational Supplement Scotland, (2353), 16.

Jirásek, I. (2004). Vymezení pojmu zážitková pedagogika. Gymnasion, 1(1), 6-16.

Kancír, J., Miňová, M., Bratková, S., Fedorko, V., Hafičová, H., Madziková, A., Sabol, M., \& Suchá, I. (2020). Environmentálna výchova pre predškolské a elementárne vzdelávanie. Vydavatel'stvo PU v Prešove.

Kane, M. J., \& Tucker, H. (2007). Sustaining adventure in New Zealand outdoor education: Perspectives from renowned New Zealand outdoor adventurers on the contested cultural understanding of adventure. Australian Journal of Outdoor Education, 11(2), 29-40.

Kariková, S. (2007). Kapitoly z pedagogickej psychológie. Pedagogická fakulta Univerzita Mateja Bela.

Kime, D. B. (2008). Outdoor Adventure education instructor teaching in postsecondary education settings: Educational connoisseurship and criticism case studies in Canada, New Zealand, and the United States. University of Denver.

Kolb, D. (1948). Experiential learning. Prentice-Hall.

Kompán, J., \& Gorner, K. (2007). Možnosti uplatnenia turistiky a pohybových aktivít v prírode $v$ spôsobe života mladej populácie. FHV UMB.

Kozík, T. (2017). Scouting in East Europe: Basic stages, examples of historiographic works, institutions of history. Altmedia.

Kudryatsev, A. (2012). The impact of enviromental education on sense of place among urban youth. Ecosphere, 3(4),1-15.

Leather, M. (2018). Outdoor education in the National Curriculum: The shifting sands in formal education. In P. Becker, B. Humberstone, C. Loynes, \& J. Schirp (Eds.), The changing world of outdoor learning in Europe (s. 179-193). Routledge.

Malome, K. (2008). Every expierience matters. Farming and Countryside Education. https:// www.ltl.org.uk/wp-content/uploads/2019/02/every-experience-matters.pdf

Neuman, J., Brtník, J., Ďoubalík, P., Šafránek, J., Vomáčko, L., \& Vomáčková, S. (2000). Turistika a sporty v př́rodě: přehled základních znalostí a dovedností pro výchovu v př́rodě. Portál.

Neuman, J. (2004). Education and learning through outdoor activities. Charles University Prague, Faculty of Physical Education and Sport.

Neuman J., Turčová, I., \& Martin, J., (2018). Czech research in outdoor experiential education. Journal of outdoor activities, 11(2), 74-78.

Nicol, R. (2002). Outdoor education: Research topic or universal value? Part one. Journal of Adventure Education \& Outdoor Learning, 2(1), 29-41.

Outdoor Institute. (2021). http://outdoor-institute.sk/

Outward Bound. (2021). What it means to be Outward Bound. https://www.outwardbound. org.au/wp-content/uploads/OBI-What-it-means-to-be-Outward-Bound-Our-LearningProcess-Explained.pdf

Parry, J., \& Allison, P. (2020). Experiential learning and outdoor education. Traditions of practice and philosophical perspectives. Routledge. 
Pathfinder. (2021). http://www.pathfinder.sk/

Prázdninová škola Lipnice. (2021). https://www.psl.cz/

Purc-Stephenson, R. J., Rawleigh, M., Kemp, H., \& Asfeldt, M. (2019). We are wilderness explorers: A review of outdoor education in Canada. Journal of experiential education, 42(4), 364-381.

Sobel, D. (2005). Place-based education: Connecting classrooms \& communities. The Orion Society.

Svobodová, H., Mísařová, D., Durna, R., Češková, T., \& Hofmann, E. (2019). Koncepce terénni výuky pro základní školy. Masaryková univerzita.

Strom života. (2021). https://stromzivota.sk/

Štátny vzdelávací ústav. (2019). Inovovaný štátny vzdelávací program pre 1. stupeň ZŠ [online]. Ministerstvo školstva Slovenskej republiky. https://www.statpedu.sk/sk/svp/inovovanystatny-vzdelavaci-program/inovovany-svp-1.stupen-zs /

YMCA Canada. (2021). https://www.ymca.ca/

Wea. (2019). Wilderness Education Association. http://wilderdom.com/history/HistoryTimeline. html

Zink R., \& Boyes, M. (2006). The nature and scope of outdoor education in New Zealand schools. Australian Journal of Outdoor Education, 10(1), 11-21.

\author{
Autor \\ doc. PaedDr. Ján Kancír, PhD., Prešovská univerzita v Prešove, Pedagogická fakulta, \\ Katedra prírodovedných a technických disciplín, Ul. 17. novembra č. 15, 08001 Prešov, \\ Slovensko, e-mail: jan.kancir@unipo.sk \\ Mgr. Sofia Šolcová, Prešovská univerzita v Prešove, Pedagogická fakulta, \\ Katedra prírodovedných a technických disciplín, Ul. 17. novembra č. 15, 08001 Prešov, \\ Slovensko, e-mail: sofia.solcova@smail.unipo.sk
}

\title{
Implementation of outdoor education in selected countries involved in Outward Bound International
}

Abstract: In the educational environment of most developed countries, the concept of outdoor education has been increasingly applied in recent decades. Staying outside is one of the important conditions for a child's healthy development. It is of great importance for their physical, cognitive, social, emotional development and contributes to the development of its key competencies. External activities have an irreplaceable role in the upbringing and education of the child. They help them understand the world around them, which is the real space of his current and future existence. From this point of view, outdoor education has an educational potential, which is irreplaceable in optimizing the complex development of the child's personality. The aim of the presented study is to point out the peculiarities of outdoor education, historical context, present and future of its application in educational practice at 
home and abroad. In the first part we deal with the philosophical background, theory and practice of experiential learning. The following is an analytical comparison of the implementation of outdoor education in selected countries that are part of the global organization dedicated to outdoor education - Outward Bound International. The comparison is based on the analysis of information sources from the full-text databases Proquest, Scopus, Web of science and others. Literary methods, analysis of pedagogical documents and literary sources of our and foreign provenance were used. Finally, we offer a brief summary of the issue in the form of a table. The study also includes proposals for the application of positive changes in educational practice in Slovakia.

Key words: outdoor education, Outward Bound International, formal and informal education, comparative analysis 